Check for updates

Cite this: RSC Adv., 2018, 8, 23252

Received 24th May 2018

Accepted 12th June 2018

DOI: $10.1039 / c 8 r a 04429 e$

rsc.li/rsc-advances

\section{Synthesis and spectroscopic investigation of a novel sensitive and selective fluorescent chemosensor for $\mathrm{Ag}^{+}$based on a BINOL-glucose derivative $\uparrow$}

\author{
Yu Hu, ${ }^{\text {ab }}$ Huayin Shen, ${ }^{a}$ Xiaohan Zhang, ${ }^{a}$ Yang Liu ${ }^{\mathrm{a}}$ and Xiaoxia Sun (D) *a
}

Based on a versatile 2,2'-binaphthol (BINOL) backbone, a novel BINOL-glucose derivative fluorescent sensor was synthesized using a click reaction. The fluorescence responses of the BINOL-glucose derivative (S, $\beta$-D)-1 conclude that it can be used as a specific fluorescent chemical sensor for $\mathrm{Ag}^{+}$in the presence of a large number of competing metal ions without any obvious interference from other metal ions. Mass spectrometric and NMR spectroscopic data were used to study the mechanism, and implied the formation of a $1+1$ complex between BINOL-glucose 1 and $\mathrm{Ag}^{+}$. Both the oxygen atoms of $\mathrm{S}$ $\mathrm{BINOL}$ and two nitrogen atoms of triazole were involved in coordinating the silver ion.

\section{Introduction}

It is very important to discover and design new highly selective fluorescent sensors that can detect heavy metal ions, which may cause serious harm to human health and the living environment. Among the important heavy metals, silver has been paid more attention because of its adverse effects on biological harmony and the environment, due to its ability to easily bind to mercapto groups in proteins and inactivate respiratory enzymes. ${ }^{1,2}$ It is very difficult to identify silver ions from other heavy metal ions because of the moderate coordination ability of $\mathrm{Ag}^{+}$. However, almost all fluorescent sensors containing triazole experience interference from other transition metals, especially from mercury ions when attempting to identify silver ions, ${ }^{3-8}$ which leads to the limitation of the use of specific fluorescent sensors for silver ions. Only a few fluorescent sensors ${ }^{9-13}$ that can detect $\mathrm{Ag}^{+}$have been reported in recent years. So, it is still a challenge to design an effective chemical method to target only $\mathrm{Ag}^{+}$.

The highly sensitive and rapid identification of isomers and metal ions is the highlight of using optically active BINOL derivatives as a fluorescent chemical sensor. With a versatile BINOL backbone, it can be easily modified through steric stabilization and electronic effects, and due to this, BINOL and its derivatives ${ }^{14-23}$ have attracted great attention in the field of fluorescent chemical sensors ${ }^{24-30}$ and synthetic catalysis.

ajiangxi Key Laboratory of Organic Chemistry, Jiangxi Science and Technology Normal University, Nanchang, 330013, China. E-mail: sunxiaoxia77@126.com ${ }^{b}$ College of Chemistry, Nanchang University, Nanchang, China

$\dagger$ Electronic supplementary information (ESI) available. See DOI: 10.1039/c8ra04429e
Moreover, sugar is a hot research topic due to its natural existence, good biocompatibility and structural diversity without being toxic. Furthermore, its good water solubility is considered to be a very ideal feature for using it as a component in fluorescent chemical sensors. In recent years, triazole modified functional sugar derivatives have attracted continuous interest in research ${ }^{31-34}$ and various sugar-based fluorescent chemosensors have been synthesized using click reactions. In this way, a novel BINOL-glucose derivative fluorescent sensor was synthesized through the Cu-catalyzed 1,3-dipolar cycloaddition $^{35-40}$ of an alkyne and azole. The synthesis was based on a versatile $(S)$-BINOL backbone, and the $(S)$-BINOL and two triazole units were used to represent the fluorophore and recognition group, respectively. The synthesized sensor could then be used as a specific fluorescent chemical sensor for $\mathrm{Ag}^{+}$in the presence of a large number of competing cations, as anticipated.

\section{Experimental}

\section{Materials and methods}

All the solvents were of analytical purity, and the materials were obtained from commercial suppliers or prepared by our laboratory, with no further purification of the commercially suppled chemicals before use. If not otherwise specified, the solvents used in the optical spectroscopic studies were of spectroscopic purity. Various metal ion solutions $(0.1 \mathrm{M})$ were prepared from their respective nitrates in distilled-deionized water, except for $\mathrm{K}^{+}, \mathrm{Hg}^{2+}, \mathrm{Mn}^{2+}$, and $\mathrm{Ba}^{2+}$, which were made from their chloride salts. $\mathrm{AgNO}_{3}$ was used as the $\mathrm{Ag}^{+}$source unless otherwise stated. ${ }^{1} \mathrm{H}$ nuclear magnetic resonance (NMR) and ${ }^{13} \mathrm{C}$ NMR were measured on a Bruker AM-400WB spectrometer using 
tetramethylsilane (TMS) as an internal standard and $\mathrm{CDCl}_{3}$ or $\mathrm{CD}_{3} \mathrm{OD}$ as solvents. All UV-Vis absorptions were recorded on an Agilent 8453 UV-Vis spectrometer. Fluorescence emission spectra were obtained using a Hitachi F-4500 fluorescence spectrometer at $298 \mathrm{~K}$, unless otherwise stated. Electrospray ionization mass spectrometric (ESI-MS) data were recorded using a Thermo Fisher LCQ. Melting points were measured on a WRS-1B melting point apparatus. Optical rotation was carried out using a Rudolph AUTOPOL IV automatic polarimeter.

\section{Synthesis of $(S, \beta-\mathrm{D})-2$}

$S$-2,2'-Bis(prop-2-yn-1-yloxy)-1,1'-binaphthalene (0.63 g, 1.75 $\mathrm{mmol}$ ) and 2,3,4,6-tetra- $O$-acetyl-beta-D-glucopyranosyl azide $(1.4 \mathrm{~g}, 3.67 \mathrm{mmol})$ were added to $50 \mathrm{~mL}$ of tetrahydrofuran (THF) with stirring at $273 \mathrm{~K}$ under an argon atmosphere and the mixture was stirred for five minutes. Sodium ascorbate $(0.69 \mathrm{~g}$, $3.48 \mathrm{mmol})$ and $\mathrm{CuSO}_{4} \cdot 5 \mathrm{H}_{2} \mathrm{O}(0.44 \mathrm{~g}, 1.76 \mathrm{mmol})$ were added to the mixture and the temperature slowly rose to room temperature, after which it was stirred for $12 \mathrm{~h}$ under $\mathrm{Ar}_{2}$. After the reaction was completed, the mixture was poured into ice water. The mixture was extracted three times with EtOAc and then the organic layer was washed with brine and dried over anhydrous $\mathrm{MgSO}_{4}$. After evaporation of the organic solvent, the crude product was purified directly by column chromatography on silica (petroleum ether $:$ EtOAc $=1: 1, \mathrm{v} / \mathrm{v}$ ) to give the desired product $(S, \beta-\mathrm{D})-2(1.7 \mathrm{~g}, 41.9 \%)$ as a white solid: $[\alpha]_{\mathrm{D}}^{25}-41.2(c$ $\left.0.1, \mathrm{CH}_{3} \mathrm{OH}\right) .{ }^{1} \mathrm{H}$ NMR $\left(400 \mathrm{MHz}, \mathrm{CDCl}_{3}\right) \delta 7.99(\mathrm{~d}, J=9.0 \mathrm{~Hz}$, $1 \mathrm{H}), 7.93(\mathrm{~d}, J=8.1 \mathrm{~Hz}, 1 \mathrm{H}), 7.49$ (d, $J=9.0 \mathrm{~Hz}, 1 \mathrm{H}), 7.39(\mathrm{t}, J=$ $7.4 \mathrm{~Hz}, 1 \mathrm{H}), 7.25$ (d, $J=7.0 \mathrm{~Hz}, 1 \mathrm{H}), 7.19-7.12(\mathrm{~m}, 2 \mathrm{H}), 5.79(\mathrm{~d}, J$ $=9.4 \mathrm{~Hz}, 1 \mathrm{H}), 5.42-5.30(\mathrm{~m}, 2 \mathrm{H}), 5.25(\mathrm{t}, J=9.2 \mathrm{~Hz}, 1 \mathrm{H}), 5.19(\mathrm{~s}$, $2 \mathrm{H}), 4.30(\mathrm{dd}, J=12.6,5.1 \mathrm{~Hz}, 1 \mathrm{H}), 4.13(\mathrm{~d}, J=12.7 \mathrm{~Hz}, 1 \mathrm{H}), 3.99$ (dd, $J=9.5,3.1 \mathrm{~Hz}, 1 \mathrm{H}), 2.11-2.02(\mathrm{~m}, 9 \mathrm{H}), 1.73(\mathrm{~d}, J=20.0 \mathrm{~Hz}$, $4 \mathrm{H}) .{ }^{13} \mathrm{C}$ NMR $\left(400 \mathrm{MHz}, \mathrm{CDCl}_{3}\right) \delta 170.32,169.57,168.55$, 153.68, 145.53, 133.93, 131.53-130.59, 130.04, 128.87, 127.29, $126.91-124.70,124.70-124.5,123.23,122.24,120.43,116.66$, 115.07, 86.28, 84.69, 77.42, 77.10, 76.78, 75.63, 74.22, 73.88, $72.06,71.00,69.46,68.38,66.85,65.10,63.41,61.94,60.21$, 22.60, 21.95, 21.30, 20.3, 19.97-19.70, 19.70-17.92 ppm. HRMS $\left(\mathrm{ESI}^{-}\right)$: calcd for $\left[\mathrm{C}_{54} \mathrm{H}_{56} \mathrm{~N}_{6} \mathrm{O}_{20}+\mathrm{Cl}\right]^{-}$1143.8; found 1143.3.

\section{Synthesis of $(S, \beta-\mathrm{D})-1$}

A mixture of ( $S, \beta$-D)-2 (1.3 g, $1.17 \mathrm{mmol}), \mathrm{NaOH}(0.47 \mathrm{~g}, 11.7$ $\mathrm{mmol})$, and methanol $(100 \mathrm{~mL})$ was stirred at room temperature for $12 \mathrm{~h}$. After the reaction was completed, the solvent was removed under reduced pressure to obtain the crude product. The product was purified directly by flash column chromatography on silica gel using dichloromethane and methanol in a ratio of $2: 1(\mathrm{v} / \mathrm{v})$ as the eluent to give the desired product 1 $(0.75 \mathrm{~g}, 82.8 \%)$ as a white solid: $[\alpha]_{\mathrm{D}}^{25}-54\left(c 0.07, \mathrm{CH}_{3} \mathrm{OH}\right) .{ }^{1} \mathrm{H}$ NMR (400 MHz, MeOD) $\delta 8.02(\mathrm{~d}, J=6.3 \mathrm{~Hz}, 1 \mathrm{H}), 7.92(\mathrm{~d}, J=$ $8.1 \mathrm{~Hz}, 1 \mathrm{H}), 7.69-7.54(\mathrm{~m}, 1 \mathrm{H}), 7.34(\mathrm{~d}, J=9.8 \mathrm{~Hz}, 2 \mathrm{H}), 7.23$ (s, $1 \mathrm{H}), 7.06$ (d, $J=8.5 \mathrm{~Hz}, 1 \mathrm{H}), 5.45$ (d, $J=9.1 \mathrm{~Hz}, 1 \mathrm{H}), 5.27-5.04$ $(\mathrm{m}, 2 \mathrm{H}), 3.87(\mathrm{~d}, J=10.9 \mathrm{~Hz}, 1 \mathrm{H}), 3.68(\mathrm{dd}, J=10.8,6.9 \mathrm{~Hz}, 2 \mathrm{H})$, 3.62-3.41 (m, 3H), 3.31 (s, 4H) ppm. ${ }^{13} \mathrm{C}$ NMR (101 MHz, MeOD) $\delta 153.77,144.31,133.93,129.77,129.49,127.90,125.73,125.16$, 123.86, 122.80, 120.48, 115.77, 87.99, 79.65, 77.19, 72.65, 69.82,
63.15-62.26, $61.12 \mathrm{ppm}$. HRMS (ESI $\left.{ }^{-}\right)$: calcd for $\left[\mathrm{C}_{40} \mathrm{H}_{44} \mathrm{~N}_{6} \mathrm{O}_{12}+\right.$ $\mathrm{Cl}]^{-}$807.2; found 807.2.

\section{Fluorescence and UV-visible measurements}

A stock solution of $(S, \beta-\mathrm{D})-\mathbf{1}\left(2.0 \times 10^{-5} \mathrm{~mol} \mathrm{~L}^{-1}\right)$ prepared in methanol and stock solutions of the metal ions $\left(0.1 \mathrm{~mol} \mathrm{~L}^{-1} \mathrm{M}\right.$ in $\mathrm{H}_{2} \mathrm{O}$ ) were freshly prepared before testing each performance. For each fluorescence quenching measurement, varying equivalents of $\mathrm{Ag}^{+}$stock solution were added to the sensor solutions in a $5 \mathrm{~mL}$ volumetric flask at $298 \mathrm{~K}$. The competition experiments involved mixing of each metal ion solution with a stock solution of $\mathrm{Ag}^{+}$of the same concentration $\left(2.0 \times 10^{-5} \mathrm{~mol} \mathrm{~L}^{-1}\right)$. The Job plot for the complexation of $(S, \beta-\mathrm{D})-\mathbf{1}$ with $\mathrm{Ag}^{+}$was obtained by recording the fluorescence response of $(S, \beta-\mathrm{D})-\mathbf{1}$ with different ratios of $\mathrm{Ag}^{+}$. A $2.0 \mathrm{mM}$ stock solution of $(S, \beta-\mathrm{D})-\mathbf{1}$ dissolved in methanol and a $2.0 \mathrm{mM} \mathrm{AgNO}_{3}$ in $\mathrm{H}_{2} \mathrm{O}$ were freshly prepared for each measurement.

\section{Preparation of the samples for NMR tests}

$\mathrm{AgNO}_{3}\left(0.1 \mathrm{M}\right.$ in $\left.\mathrm{D}_{2} \mathrm{O}\right)$ was gradually added to an NMR tube containing $(S, \beta$-D)-1 $(0.4 \mathrm{~mL}, 25 \mathrm{mM})$ to obtain $1: 0,1: 0.1$, $1: 0.3,1: 0.5,1: 0.7$, and $1: 1$ ratios of the sensor to $\mathrm{Ag}^{+}$. The resulting solutions were allowed to equilibrate at $298 \mathrm{~K}$ for $4 \mathrm{~h}$ before testing.

\section{Results and discussion}

The BINOL-glucose derivative fluorescent sensor was synthesized using "click chemistry", as shown in Scheme 1. According to the previous literature, the dipropargyl 3 (ref. 41) derivative of $(S)$-BINOL was prepared (Scheme 1). The reaction of dipropargyl 3 and azide-functionalized glucose $\mathbf{4}$ was carried out in THF at room temperature in the presence of sodium ascorbate and copper(II) sulfate to afford BINOL-glucose derivative 2 in moderate yield after a simple purification process. The new fluorescent sensor $\mathbf{1}$ was obtained when $\mathbf{2}$ was hydrolyzed in methanol, in $83 \%$ yield. The structures of the desired compounds were determined from ${ }^{1} \mathrm{H}$ NMR, ${ }^{13} \mathrm{C}$ NMR, and ESIMS measurements.

\section{Fluorescence study}

The fluorescence responses of $(S, \beta-\mathrm{D})$-1 were studied in the presence of $\mathrm{Ag}^{+}, \mathrm{Ba}^{2+}, \mathrm{Cd}^{2+}, \mathrm{Mg}^{2+}, \mathrm{Ca}^{2+}, \mathrm{Cr}^{3+}, \mathrm{Al}^{3+}, \mathrm{Ca}^{2+}, \mathrm{Co}^{2+}$, $\mathrm{Cu}^{2+}, \mathrm{K}^{+}, \mathrm{Ni}^{2+}, \mathrm{Mn}^{2+}, \mathrm{Zn}^{2+}, \mathrm{Hg}^{2+}, \mathrm{Sn}^{2+}, \mathrm{Pb}^{2+}$, and $\mathrm{Sr}^{2+}$ ions in
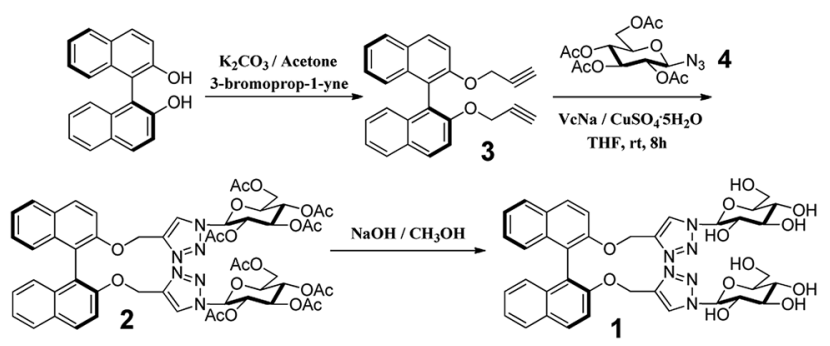

Scheme 1 Synthetic route for compound $(S, \beta-D)-1$. 


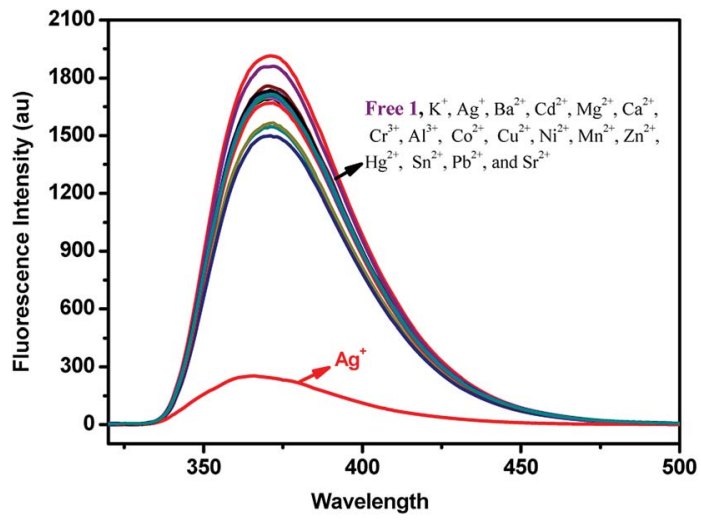

Fig. 1 Fluorescence spectra of $1\left(2 \times 10^{-5} \mathrm{~mol} \mathrm{~L}^{-1}\right.$ in $\left.\mathrm{CH}_{3} \mathrm{OH}\right)$ upon the addition of $\mathrm{K}^{+}, \mathrm{Ag}^{+}, \mathrm{Ba}^{2+}, \mathrm{Cd}^{2+}, \mathrm{Mg}^{2+}, \mathrm{Ca}^{2+}, \mathrm{Cr}^{3+}, \mathrm{Al}^{3+}, \mathrm{Co}^{2+}, \mathrm{Cu}^{2+}$, $\mathrm{Ni}^{2+}, \mathrm{Mn}^{2+}, \mathrm{Zn}^{2+}, \mathrm{Hg}^{2+}, \mathrm{Mn}^{2+}, \mathrm{Sn}^{2+}, \mathrm{Pb}^{2+}$, and $\mathrm{Sr}^{2+}$ ions (5 equiv.).

different solutions using fluorescence spectroscopy. First, the fluorescence measurements of $(S, \beta-\mathrm{D})-\mathbf{1}$ were carried out in $\mathrm{CH}_{3} \mathrm{OH}([(S, \beta-\mathrm{D})-\mathbf{1}]=20 \mu \mathrm{M})$. As shown in Fig. 1, only the addition of $\mathrm{Ag}^{+}$ions to a solution of $(S, \beta-\mathrm{D})-\mathbf{1}$ could result in an almost complete quenching of the fluorescence, however, other metal ions induced no obvious change in the fluorescence response. When the fluorescence selectivity experiments of $(S, \beta$ D)-1 were tested in THF solution (as shown in Fig. S8†), no significant difference in the fluorescence response was found. The discrimination between the different metal ions showed a sensitive dependence on the solvent. So, all of the fluorescence measurements of $(S, \beta$-D)-1 were investigated in methanol solution, in which $(S, \beta-\mathrm{D})-\mathbf{1}$ was found to be highly selective and sensitive towards $\mathrm{Ag}^{+}$. An unexpected quenching of the fluorescence of the excimer emission upon addition of $\mathrm{Ag}^{+}$ions to a solution of $\mathbf{1}$ may be due to PET (photoinduced electron transfer). In other words, the metal ions combined with electron acceptor triazole units and the glucose units behaved as a PET donor. This means that the two triazole units of $(S, \beta-\mathrm{D})-\mathbf{1}$ form a selective and effective metal ion binding site.

\section{Metal ion competition studies}

For an effective cation probe, the key factor is the ability to detect a specific metal ion in the presence of different metal ions. Fig. 2 shows the results of competition experiments we conducted in which we tested the ability of the probe to selectively detect one metal ion over other metal ions. The addition of 5.0 equiv. of $\mathrm{Ag}^{+}$combined with 5.0 equiv. of the other metal ions in methanol solutions of $(S, \beta-\mathrm{D})-\mathbf{1}$, respectively, were used in the competitive experiments. The quenching ratio of the $I_{\mathrm{F}} / I_{0}$ value at $375 \mathrm{~nm}$ (where $I_{0}$ represents the fluorescence intensity of only $(S, \beta-\mathrm{D})-\mathbf{1}$ and $I_{\mathrm{F}}$ represents the fluorescence intensity upon the addition of a mixture of competitive metal ions and $\mathrm{Ag}^{+}$) for the majority of the competitive metal ions was almost 0.17 . No significant interference was observed in the presence of the various competitive metal ions. This indicated that the BINOL-glucose sensor could be used to detect $\mathrm{Ag}^{+}$in the presence of various competitive ions without any obvious

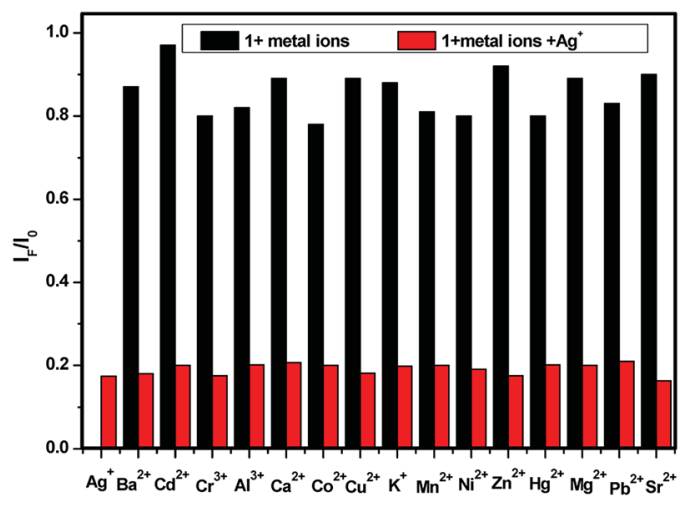

Fig. 2 Fluorescence quenching degrees in terms of the $I_{F} / I_{0}$ ratio of 1 $\left(2 \times 10^{-5} \mathrm{~mol} \mathrm{~L}^{-1}\right.$ in methanol) in the presence of both $\mathrm{Ag}^{+}$(5.0 equiv.) and competing metal ions (5.0 equiv.). The black bars represent the addition of 5 equiv. of various metal ions to a solution of 1 , and the red bars represent the competing metal ion added in the presence of $\mathrm{Ag}^{+}$.

interference from the other metal ions. Based on the fluorescence results, we found that the BINOL-glucose derivative has high selectivity and sensitivity to $\mathrm{Ag}^{+}$and therefore can be used as an $\mathrm{Ag}^{+}$sensor.

The binding tests of $(S, \beta-\mathrm{D})-\mathbf{1}$ towards $\mathrm{Ag}^{+}$were also studied upon the addition of different amounts of $\mathrm{Ag}^{+}$to $(S, \beta-\mathrm{D})-\mathbf{1}$ in $\mathrm{CH}_{3} \mathrm{OH}$, using UV-Vis absorption spectroscopy. As shown in Fig. 3, the maximum absorption wavelength of $(S, \beta-\mathrm{D})-\mathbf{1}$ was found to be around $229 \mathrm{~nm}$ upon the addition of 0 to 3 equivalent of $\mathrm{Ag}^{+}$. However, there was found to be a slight change in the UV-Vis absorption spectrum of $(S, \beta-\mathrm{D})-\mathbf{1}$ in the presence of various concentrations of $\mathrm{Ag}^{+}$, where the absorbance at $210 \mathrm{~nm}$ was observed to begin to increase, which may indicate the formation of a $(S, \beta-\mathrm{D})-\mathbf{1}-\mathrm{Ag}^{+}$complex. It is a pity that the slight absorbance intensity shift did not induce any obvious color change. The interaction between the host and guest was evaluated using fluorescence spectroscopy. From Fig. 3, it can be seen that $(S, \beta$-D)-1 has three absorption peaks at $229 \mathrm{~nm}$, $290 \mathrm{~nm}$ and $335 \mathrm{~nm}$. The maximum absorption wavelength $\lambda_{\max }$ of $(S, \beta-\mathrm{D})$-1 was around $229 \mathrm{~nm}$ with weak fluorescence emission. However, the absorption at $290 \mathrm{~nm}$ was observed to have a stronger fluorescence intensity (see Fig. S9†), and so, $\lambda_{\mathrm{ex}}=$ $290 \mathrm{~nm}$.

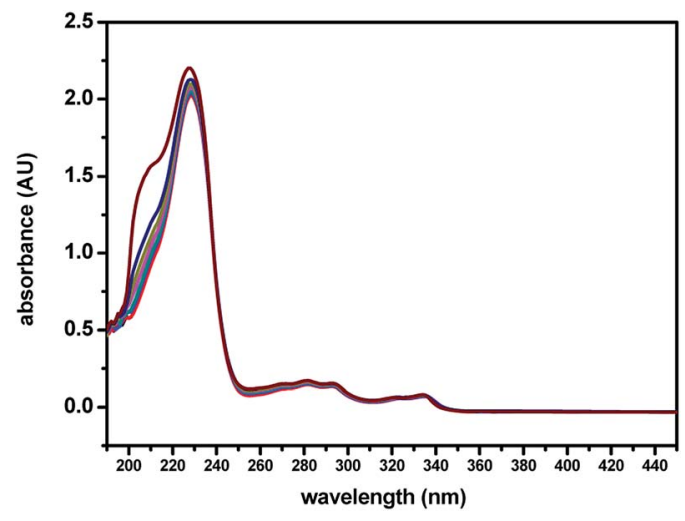

Fig. 3 UV-Vis spectroscopic titrations of $(S, \beta-D)-1(20 \mu \mathrm{M})$ with various equivalents of $\mathrm{Ag}^{+}\left(0,0.25,0.5,0.75,1,1.5,2,3\right.$ equiv.) in $\mathrm{CH}_{3} \mathrm{OH}$. 


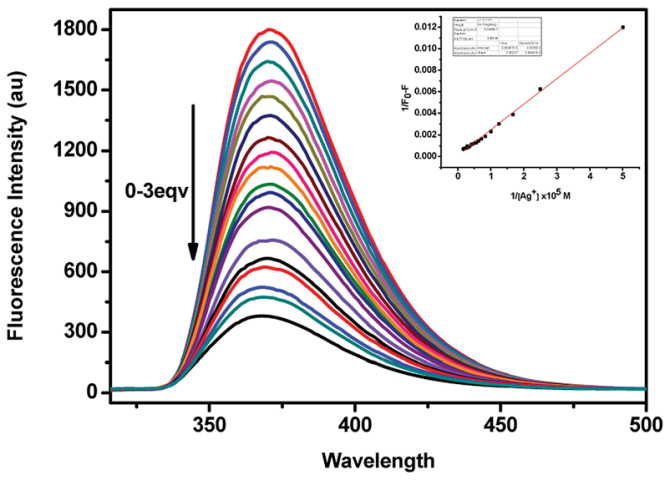

Fig. 4 Fluorescence spectra of $1\left(2 \times 10^{-5} \mathrm{~mol} \mathrm{~L}^{-1}\right.$ in $\mathrm{CH}_{3} \mathrm{OH}, \lambda_{\text {ex }}=$ $290 \mathrm{~nm}$ ) in the presence of an increasing amount of $0-3$ equiv. of $\mathrm{Ag}^{+}$ $(0.01 \mathrm{M})$. The inset shows the plot of $1 /\left(F_{0}-F\right)$ versus $1 /\left[\mathrm{Ag}^{+}\right]$.

As shown in Fig. 4, the fluorescence spectra of $(S, \beta$-D)-1 upon adding different equivalents of $\mathrm{Ag}^{+}$were used to determine the nature of the complex formed between $(S, \beta-\mathrm{D})-\mathbf{1}$ and $\mathrm{Ag}^{+}$. When the amount of $\mathrm{Ag}^{+}$used was above 3 equiv., the intensity of the fluorescence emission underwent a strong change. We assumed that the stoichiometry ratio of $(S, \beta-\mathrm{D})-\mathbf{1}-\mathrm{Ag}^{+}$complex is $1: 1$, so the association constant $K$ of $(S, \beta-\mathrm{D})-\mathbf{1}$ with $\mathrm{Ag}^{+}$was found to be $2.4 \times 10^{6} \mathrm{M}^{-1}(R=0.997)$ from the Lineweaver-Burk plot of $1 /$ $\left(F_{0}-F\right)$ versus $1 /\left[\mathrm{Ag}^{+}\right]$. As shown in Fig. 5 , the maximum fluorescence quenching of $(S, \beta-\mathrm{D})-\mathbf{1}$ provided by $\mathrm{Ag}^{+}$takes place at a ratio of $1: 1$. Based on the fluorescence analyses, the BINOLglucose compound and $\mathrm{Ag}^{+}$were proposed to form a $1+1$ complex. The Job plot for the complex provided further direct evidence that the $(S, \beta-\mathrm{D})-\mathbf{1}-\mathrm{Ag}^{+}$complex stoichiometry ratio was $1: 1$. Respectively, the detection limit (LOD) of $(S, \beta-\mathrm{D})-\mathbf{1}$ to $\mathrm{Ag}^{+}$ was assessed to be $1.57 \times 10^{-9} \mathrm{~mol} \mathrm{~L}^{-1}$ using the following equation: $\mathrm{LOD}=3 \sigma / s$, where $\sigma$ represents the standard deviation of the $(S, \beta-\mathrm{D})$-1 $\mathbf{1}$ solution and $s$ represents the slope between the fluorescence intensity versus the $\mathrm{Ag}^{+}$concentration (Fig. S11 $\dagger$ ). Further evidence for the $1: 1$ complex stoichiometry ratio was obtained from ESI-MS spectra data (see Fig. S7, ESI data $\dagger$ ). The peak at $m / z=881.1$ (calcd 881) was found to

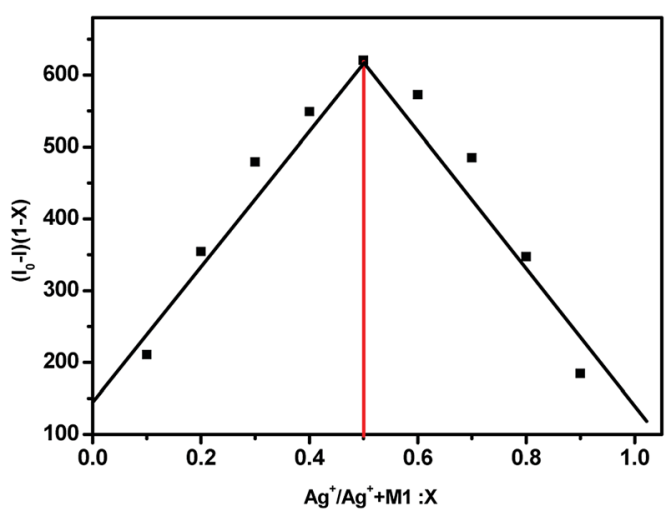

Fig. 5 The Job plot of a $1: 1$ complex of $(S, \beta-D)-1$ with $\mathrm{Ag}^{+}$on the basis of the fluorescence signal. $X$ represents the molar fraction of $\mathrm{Ag}^{+}$. The total concentration of $(S, \beta-D)-1$ and $\mathrm{Ag}^{+}$was found to be $2.0 \times$ $10^{-5} \mathrm{M}$.
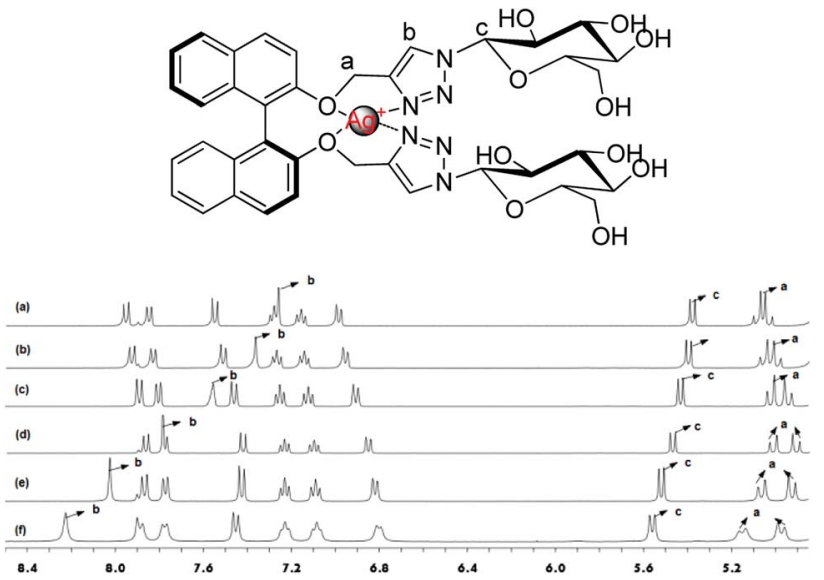

Fig. $6{ }^{1} \mathrm{H}$ NMR spectra of (a) 1 ; (b) the addition of 0.1 equiv. of $\mathrm{Ag}^{+}$; (c) the addition of 0.3 equiv. of $\mathrm{Ag}^{+}$; (d) the addition of 0.5 equiv. of $\mathrm{Ag}^{+}$; (e) the addition of 0.7 equiv. of $\mathrm{Ag}^{+}$; (f) the addition of 1 equiv. of $\mathrm{Ag}^{+}$.

correspond to $\left[\mathbf{1}-\mathrm{Ag}^{+}+\mathrm{H}^{+}\right]$, which supports our assumption there is strong binding between $\left(S, \beta\right.$-D)-1 and $\mathbf{A g}^{+}$.

The ${ }^{1} \mathrm{H}$ NMR experiments were carried out in $\mathrm{CD}_{3} \mathrm{OD}$ to find out further detailed information on the binding of $\mathrm{Ag}^{+}$with $(S, \beta$-D)-1. As shown in Fig. 6, different equiv. (from 0 to 1 equiv.) of $\mathrm{Ag}^{+}$were added to a solution of $(S, \beta-\mathrm{D})-\mathbf{1}$ and resulted in an obvious downshift in the chemical shifts, however, the shifts tended to saturation when the amount of $\mathrm{Ag}^{+}$was beyond 1 equiv. The $\mathrm{H}_{\mathrm{a}}$ nuclear magnetic peaks of the $-\mathrm{OCH}_{2}-$ linking triazole groups are split into two sets of signals; a group of displacement peaks migrate $\Delta \delta 0.11 \mathrm{ppm}$ downfield from $5.05 \mathrm{ppm}$ to $5.16 \mathrm{ppm}$, while another group of displacement peaks shift up field by $0.09 \mathrm{ppm}$, from $5.05 \mathrm{ppm}$ to $4.96 \mathrm{ppm}$. These changes demonstrate that $\mathrm{Ag}^{+}$is selectively bound to the BINOL-glucose sensor through the oxygen atoms on the BINOL. The $\mathrm{H}_{\mathrm{c}}$ peak of the glucose linked to the triazole groups exhibited a smaller chemical shift from $5.31 \mathrm{ppm}$ to $5.54 \mathrm{ppm}$. In particular, the $\mathrm{H}_{\mathrm{b}}$ peak of the triazole rings was observed to undergo an obvious downshift of $\Delta \delta=0.97 \mathrm{ppm}$ from $7.26 \mathrm{ppm}$ to $8.23 \mathrm{ppm}$. From the above data, we concluded that both of the oxygen atoms of the BINOL and the nitrogen atoms on the triazole of $(S, \beta-\mathrm{D})$-1 were involved in the formation of a tetrahedral complex with a silver ion at the center. The results obtained from fluorescence and NMR spectroscopic and mass spectrometric analyses were also used to confirm the recognition between the BINOL-glucose compound and $\mathrm{Ag}^{+}$in a $1+1$ complex.

\section{Conclusions}

In summary, through a four step reaction, a novel highly selective and sensitive BINOL-glucose derivative fluorescent sensor $(S, \beta-\mathrm{D})-\mathbf{1}$ that can detect $\mathrm{Ag}^{+}$was synthesized with an overall yield of $30 \%$. ( $S, \beta-\mathrm{D})-\mathbf{1}$ was observed to function as an $\mathrm{Ag}^{+}$ specific fluorescent sensor, as it showed high sensitivity and specificity in the experiments. The highly selective fluorescence turn-off behavior was caused by the formation of a $1+1$ binding 
complex between BINOL-glucose 1 and $\mathrm{Ag}^{+}$without any interference from various different metal ions. The fluorescence quenching was ascribed to both the triazole nitrogen atoms and the oxygen atoms of $(S, \beta-\mathrm{D})-\mathbf{1}$ involved in the coordination with $\mathrm{Ag}^{+}$. These results show the possibility of preparing highly selective fluorescent sensors based on the versatile BINOL backbone for the detection of various metal ions.

\section{Conflicts of interest}

There are no conflicts to declare.

\section{Acknowledgements}

The authors are grateful for the financial support of the National Natural Science Foundation of China (No. 21462018), the Science Fund of the Technology Office of Jiangxi, China (2009ZDS11100 and 20132BBE50024), and the Jiangxi Science and Normal Technology Normal University Program for Science Research Innovation Team (2013CXTD00 2).

\section{Notes and references}

1 H. T. Ratte, Environ. Toxicol. Chem., 1999, 18, 89.

2 A. T. Wan, R. A. Conyers, C. J. Coombs and J. P. Masterton, Clin. Chem., 1991, 37, 1683.

3 S.-K. Ko, Y.-K. Yang, J. Tae and I. Shin, J. Am. Chem. Soc., 2006, 128, 14150.

4 E. M. Nolan and S. J. Lippard, J. Am. Chem. Soc., 2003, 125, 14270-14271.

5 J. Huang, Y. Xu and X. Qian, J. Org. Chem., 2009, 74, 21672170.

6 Q. Y. Chen and C. F. Chen, Tetrahedron Lett., 2005, 46, 165168.

7 M. Yuan, Y. Li, J. Li, C. Li, X. Liu, J. Lv, J. Xu, H. Liu, S. Wang and D. Zhu, Org. Lett., 2007, 9, 2313-2316.

8 M. Yuan, W. Zhou, X. Liu, M. Zhu, J. Li, X. Yin, H. Zheng, Z. Zuo, C. Ouyang, H. Liu, Y. Li and D. Zhu, J. Org. Chem., 2008, 73, 5008-5014.

9 J. Hou, Q. Zhang, B. Xu, Q. Lu, Q. Liu, J. Zhang and X. Yu, Tetrahedron Lett., 2011, 52, 4927-4930.

10 M. Zhu, Y. Zhou, L. Yang, L. Li, D. Qi, M. Bai, Y. Chen, H. Du and Y. Bian, Inorg. Chem., 2014, 53, 12186-12190.

11 J.-F. Zhang, Y. Zhou, J. Yoon and J. S. Kim, Chem. Soc. Rev., 2011, 40, 3416-3429.

12 X. Liu, X. Yang, H. Peng, C. Zhu and Y. Cheng, Tetrahedron Lett., 2011, 52, 2295-2298.

13 X. C. Liu, X. Yang, Y. Fu and C. J. Zhu, Tetrahedron, 2011, 67, 3181-3186.

14 V. Pugh, Q.-S. Hu and L. Pu, Angew. Chem., Int. Ed., 2000, 39, 3638-3641.
15 J. Lin, Q.-S. Hu, M. H. Xu and L. Pu, J. Am. Chem. Soc., 2002, 124, 2088-2089.

16 M.-H. Xu, J. Lin, Q.-S. Hu and L. Pu, J. Am. Chem. Soc., 2002, 124, 14239-14246.

17 Z.-B. Li, J. Lin and L. Pu, Angew. Chem., Int. Ed., 2005, 44, 1690-1693.

18 H.-L. Liu, X.-L. Hou and L. Pu, Angew. Chem., Int. Ed., 2009, 48, 382-385.

19 H.-L. Liu, Q. Peng, Y.-D. Wu, D. Chen, X.-L. Hou, M. Sabat and L. Pu, Angew. Chem., Int. Ed., 2010, 49, 602-606.

20 X. Chen, Z. Huang, S.-Y. Chen, K. Li, X.-Q. Yu and L. Pu, J. Am. Chem. Soc., 2010, 132, 7297-7299.

21 S. Yu and L. Pu, J. Am. Chem. Soc., 2010, 132, 17698-17700. 22 L. Pu, Acc. Chem. Res., 2012, 45, 150-163.

23 C. Wang, C. Zeng, X. Zhang and L. Pu, J. Org. Chem., 2017, 82, 12669-12673.

24 L. Pu, Chem. Rev., 1998, 98, 2405-2494.

25 L. Pu, Chem. Rev., 2004, 104, 1687.

26 L. Pu, Acc. Chem. Res., 2017, 50, 1032-1040.

27 T. Song, Y. Cao, G. Zhao and L. Pu, Inorg. Chem., 2017, 56, 4395-4399.

28 S. Maisoneuve and R. Metivier, J. Org. Chem., 2007, 72, 59805985.

29 Y.-C. Hsieh, J.-L. Chir, H.-H. Wu and A.-T. Wu, Tetrahedron Lett., 2010, 51, 109-111.

30 X. P. He and Z. Song, Tetrahedron, 2011, 67, 3343-3347.

31 L. Lin, Q. Shen, G.-R. Chen and X. Juan, Bioorg. Med. Chem. Lett., 2008, 18, 6348-6351.

32 Y.-J. Zhang, X.-P. He, C. Li, Z. Li, D.-T. Shi, L.-X. Gao, B.-Y. Qiu, X.-X. Shi, Y. Tang, J. Li and G.-R. Chen, Chem. Lett., 2010, 39, 1261-1263.

33 Z. Song, X.-P. He, C. Li, L.-X. Gao, Z.-X. Wang, Y. Tang, J. Xie, J. Li and G.-R. Chen, Carbohydr. Res., 2011, 346, 140-145.

34 X.-P. He, C. Li, X.-P. Jin, Z. Song, H.-L. Zhang, C.-J. Zhu, Q. Shen, W. Zhang, L. sheng, X.-X. Shi, Y. Tan, J. Li, G.-R. Chen and J. Xie, New J. Chem., 2011, 35, 622-631.

35 H. C. Kolb, M. G. Finn and K. B. Sharpless, Angew. Chem., Int. Ed., 2001, 40, 2004-2021.

36 V. V. Rostovstev, L. G. Green, V. V. Fokin and K. B. Sharpless, Angew. Chem., Int. Ed., 2002, 41, 2596-2599.

37 C. W. Tornoe, C. Christensen and M. Meldal, J. Org. Chem., 2002, 67, 3057-3064.

38 Y.-R. Hua and A. H. Flood, Chem. Soc. Rev., 2010, 39, 12621271.

39 Y. H. Lau, P. J. Rutledge, M. Watkinson and M. H. Todd, Chem. Soc. Rev., 2011, 40, 2848.

40 H. Struthers, T. L. Mindt and R. Schibli, Dalton Trans., 2010, 675-679.

41 R. Rajakumar, R. Anandhan and V. Kalpana, Synlett, 2009, 1417-1422. 